This document was prepared in conjunction with work accomplished under Contract No. DE-AC09-96SR18500 with the U. S. Department of Energy.

\title{
DISCLAIMER
}

This report was prepared as an account of work sponsored by an agency of the United States Government. Neither the United States Government nor any agency thereof, nor any of their employees, nor any of their contractors, subcontractors or their employees, makes any warranty, express or implied, or assumes any legal liability or responsibility for the accuracy, completeness, or any third party's use or the results of such use of any information, apparatus, product, or process disclosed, or represents that its use would not infringe privately owned rights. Reference herein to any specific commercial product, process, or service by trade name, trademark, manufacturer, or otherwise, does not necessarily constitute or imply its endorsement, recommendation, or favoring by the United States Government or any agency thereof or its contractors or subcontractors. The views and opinions of authors expressed herein do not necessarily state or reflect those of the United States Government or any agency thereof. 


\section{DEVELOPMENT OF MONOSODIUM TITANATE (MST) PURCHASE SPECIFICATIONS}

by

DAVID HOBBS

Westinghouse Savannah River Company

Savannah River Site

Aiken, South Carolina 29808

Additional Authors:

This paper was prepared in connection with work done under the above contract number with the U. S.

Department of Energy. By acceptance of this paper, the publisher and/or recipient acknowledges the U. S. Government's right to retain a nonexclusive, royalty-free license in and to any copyright covering this paper, along with the right to reproduce and to authorize others to reproduce all or part of the copyrighted paper. 
WSRC-TR-2006-00039

Revision 0

Key Words:

waste

radiochemical

separation

strontium

actinide

Retention: Permanent

\title{
DEVELOPMENT OF MONOSODIUM TITANATE (MST) PURCHASE SPECIFICATIONS
}

\author{
D. T. Hobbs
}

M. R. Poirier

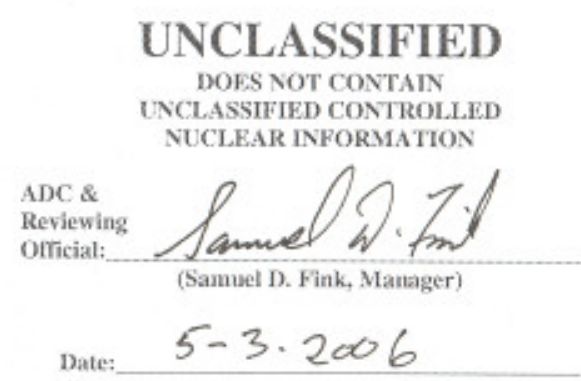

\section{APRIL 2006}

Savannah River National Laboratory

Washington Savannah River Company

Savannah River Site

Aiken. SC 29808

Prepared for the U.S. Department of Energy Under

Contract Number DE-AC09-96SR18500

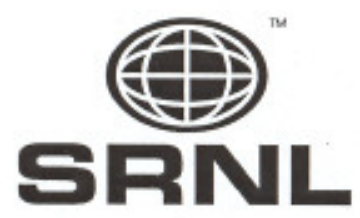




\section{DISCLAIMER}

This report was prepared for the United States Department of Energy under Contract No. DE-AC09-96SR18500 and is an account of work performed under that contract. Neither the United States Department of Energy, nor WSRC, nor any of their employees makes any warranty, expressed or implied, or assumes any legal liability or responsibility for accuracy, completeness, or usefulness, of any information, apparatus, or product or process disclosed herein or represents that its use will not infringe privately owned rights. Reference herein to any specific commercial product, process, or service by trade name, trademark, name, manufacturer or otherwise does not necessarily constitute or imply endorsement, recommendation, or favoring of same by Washington Savannah River Company or by the United States Government or any agency thereof. The views and opinions of the authors expressed herein do not necessarily state or reflect those of the United States Government or any agency thereof.

Printed in the United States of America

Prepared For

U.S. Department of Energy 
Key Words: waste radiochemical separation strontium actinide

Retention: Permanent

\title{
DEVELOPMENT OF MONOSODIUM TITANATE (MST) PURCHASE SPECIFICATION
}

\author{
D. T. Hobbs \\ M. R. Poirier
}

APRIL 2006

Savannah River National Laboratory

Washington Savannah River Company

Savannah River Site

Aiken, SC 29808 
WSRC-TR-2006-00039

Revision 0

REVIEWS AND APPROVALS

D.T.thL

$4 / 12 / 06$

D. T. Hobbs, Co-author, Process Chemistry and Science

Date

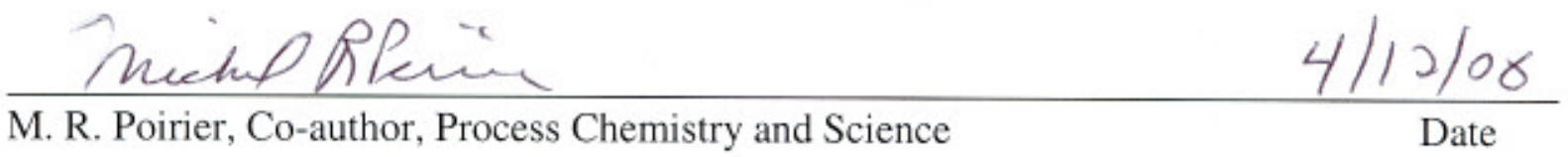

Thomson B. Peter o

$4-12.2006$

T. B. Peters, Reviewer, Process Chemistry and Science

Date

Samuel T. Fink

$4-12 \cdot 2006$

S. D. Fink, Manager, Process Chemistry and Science

Date
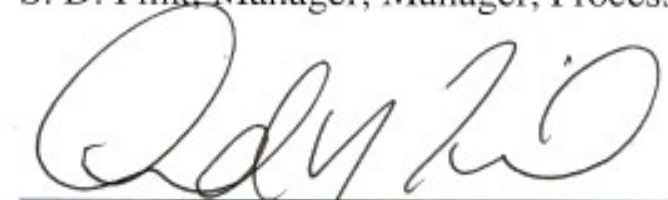

A. J. Tisler, Manager, Salt Disposition Engineering

$5 / 2 / 06$

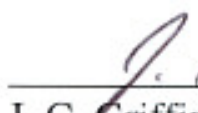

J. C. Griffin, Manager, Chemical Science and Technology

Date

- ii - 


\section{TABLE OF CONTENTS}

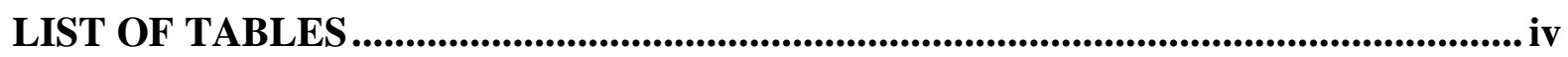

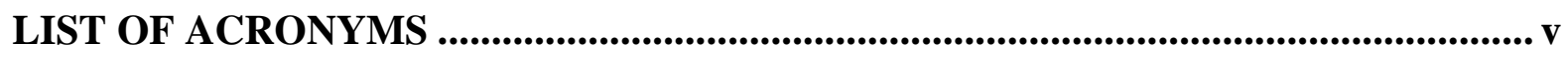

1.0 EXECUTIVE SUMMARY .............................................................................................. 1

2.0 INTRODUCTION.................................................................................................... 2

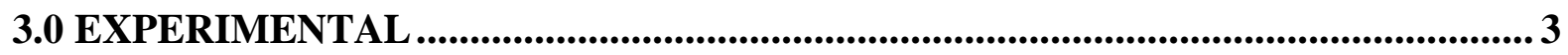

4.0 RESULTS AND DISCUSSION

4.1 PARTICLE SIZE SPECIFICATION ......................................................................... 4

4.2 STRONTIUM DECONTAMINATION FACTOR (DF) SPECIFICATION ........... 7

5.0 CONCLUSION AND RECOMMENDATIONS........................................................... 11

6.0 REFERENCES .............................................................................................................. 12 


\section{LIST OF TABLES}

Table 1. Composition of Simulated Waste Solutions .................................. 3

Table 2. MST Particle Size Data Based on Measurements Performed

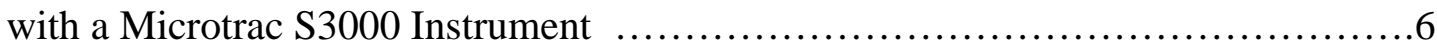

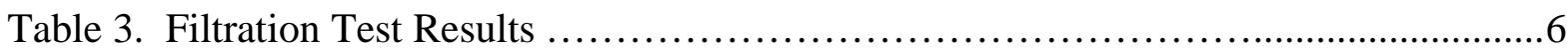

Table 4. Particle Size Specifications for Acceptance of MST ….........................

Table 5. Strontium, Plutonium and Neptunium Decontamination Factors $\ldots \ldots \ldots \ldots \ldots \ldots$ 


\section{LIST OF ACRONYMS}

$\begin{array}{ll}\text { ARP } & \text { Actinide Removal Process } \\ \text { ICP-ES } & \text { inductively coupled plasma emission spectroscopy } \\ \text { ICP-MS } & \text { inductively coupled plasma mass spectroscopy } \\ \text { ITP } & \text { In-Tank Precipitation } \\ \text { MST } & \text { monosodium titanate } \\ \text { SRS } & \text { Savannah River Site } \\ \text { SRNL } & \text { Savannah River National Laboratory }\end{array}$




\subsection{EXECUTIVE SUMMARY}

Savannah River National Laboratory (SRNL) evaluated the previous monosodium titanate (MST) purchase specifications for particle size and strontium decontamination factor. Based on the measured particle size and filtration performance characteristics of several MST samples with simulated waste solutions and various filter membranes we recommend changing the particle size specification as follows. The recommended specification varies with the size and manufacturer of the filter membrane as shown below. We recommend that future batches of MST received at SRS be tested for particle size and filtration performance. This will increase the available database and provide increased confidence that particle size parameters are an accurate prediction of filtration performance.

\section{Filter Media $0.1 \mu$ Pall \\ $0.1 \mu \mathrm{Mott}$}

$\begin{array}{llcc}\frac{\mathbf{0 . 1 \mu} \mu}{<10 \mathrm{vol} \%} & \leq \mathbf{0 . 8 \mu} & \frac{\mathbf{3 7 \mu} \mu}{1 \mathrm{vol} \%} & \begin{array}{c}\text { Geometric } \\ \text { Std. Dev. }\end{array} \\ & <10 \mathrm{vol} \% & <1 \mathrm{vol} \% & \leq 3.5\end{array}$

Testing demonstrated the feasibility of a non-radiochemical method for evaluating strontium removal performance of MST samples. Using this analytical methodology we recommend that the purchase specification include the requirement that the MST exhibits a strontium DF factor of $>1.79$ upon contact with a simulated waste solution with composition as reported for simulated waste solution SWS-7-2005-1 in Table 1 and containing 5.2 to $5.7 \mathrm{mg} \mathrm{L}^{-1}$ strontium with $0.1 \mathrm{~g} \mathrm{~L}^{-1}$ of the MST. We also recommend performing additional tests with these simulants and MST samples and, if available, new MST samples, to determine the reproducibility and increase the available database for the measurements by the ICP-ES instrument. These measurements will provide increased confidence that the non-radiological method provides a reliable method for evaluating the strontium and actinide removal performance for MST samples. 


\subsection{INTRODUCTION}

The current design for the Actinide Removal Process (ARP) uses MST to remove strontium and alpha-emitting radionuclides from nuclear waste solutions generated at the Savannah River Site (SRS). The MST solids are concentrated by crossflow filtration, washed to reduce dissolved salts and transferred to the Defense Waste Processing Facility for disposition in high level waste glass. Currently, the procurement of MST uses specifications largely developed for the now abandoned In-Tank Precipitation (ITP) process. Implementing the MST sorption/ion exchange technology within the 512-S and 241-96H facilities represents a significant configuration change from that in the ITP operation. Furthermore, plans are to use a smaller pore diameter crossflow filter membrane in the ARP operation.

Given these changes, the ARP design authority requested that Savannah River National Laboratory (SRNL) assess and recommend modifications to the specifications, as appropriate, for the procurement of MST. ${ }^{1}$ Key deliverables in this request are quantifying the acceptable particle size to obtain good filtration flux and developing a non-radioactive method for qualifying purchased material that ensures the MST batch exhibits the required degree of removal for ${ }^{90} \mathrm{Sr}$ and alpha-emitting radionuclides. This report documents testing and recommendations for modifying the purchase specifications for MST according to the approved scope of work detailed in the task technical and quality assurance plan. ${ }^{2}$ 


\subsection{EXPERIMENTAL}

\subsection{Simulated Waste Solutions}

Testing of strontium and actinide removal performance used one of the three simulated waste solution compositions as shown in Table 1. The bulk chemical composition of the simulants is identical to that developed for testing the performance of MST in support of the development of salt processing facilities at SRS. ${ }^{3,4}$ The simulant identified as SSS-8-2004 includes plutonium, uranium, and neptunium in addition to ${ }^{85} \mathrm{Sr}$. This simulant features a relatively low stable strontium concentration. The other two simulants, SWS-7-2005-1 and SWS-7-2005-2, feature much higher stable strontium concentrations without plutonium, neptunium and uranium. Simulant SWS-7-2005-2 was spiked with a radiotracer, ${ }^{85} \mathrm{Sr}$, to allow determination of strontium removal by gamma counting.

\section{Table 1. Composition of Simulated Waste Solutions}

\begin{tabular}{|c|c|c|c|c|}
\hline Component & Unit & SSS-8-2004 & SWS-7-2005-1 ${ }^{\mathrm{a}}$ & SWS-7-2005- $2^{\mathrm{a}}$ \\
\hline $\mathrm{NaNO}_{3}$ & $\mathrm{M}$ & $2.44 \pm 0.24$ & 2.60 & 2.60 \\
\hline $\mathrm{NaOH}$ & M & $1.36 \pm 0.24$ & 1.33 & 1.33 \\
\hline $\mathrm{Na}_{2} \mathrm{SO}_{4}$ & M & $0.551 \pm 0.055$ & 0.521 & 0.521 \\
\hline $\mathrm{NaAl}(\mathrm{OH})_{4}$ & M & $0.503 \pm 0.050$ & 0.429 & 0.429 \\
\hline $\mathrm{NaNO}_{2}$ & M & $0.116 \pm 0.012$ & 0.134 & 0.134 \\
\hline $\mathrm{Na}_{2} \mathrm{CO}_{3}$ & M & $0.016 \pm 0.010$ & 0.026 & 0.026 \\
\hline Total $\mathrm{Na}$ & M & $5.2 \pm 0.52$ & 5.6 & 5.6 \\
\hline Total Sr & $\mathrm{mg} \mathrm{L}^{-1}$ & $0.484+0.032$ & $5.23 \pm 0.193$ & $5.66 \pm 0.16$ \\
\hline${ }^{85} \mathrm{Sr}$ & $\mathrm{dpm} \mathrm{mL}^{-1}$ & $38,000+655$ & 0 & $80,600+260$ \\
\hline Total Pu & $\mathrm{mg} \mathrm{L}^{-1}$ & $0.229 \pm 0.3 .74$ & 0 & 0 \\
\hline${ }^{237} \mathrm{~Np}$ & $\mathrm{mg} \mathrm{L}^{-1}$ & $0.46 \overline{6}+64$ & 0 & 0 \\
\hline Total U & $\mathrm{mg} \mathrm{L}^{-1}$ & $9.55 \pm 0.33$ & 0 & 0 \\
\hline Total Sorbate & & & & \\
\hline Cation Equivalents & $\mathrm{mM}$ & $0.0971 \pm 0.0044$ & $0.119 \pm 0.0044$ & $0.129 \pm 0.0037$ \\
\hline
\end{tabular}

\subsection{Measurement of Strontium and Actinide Removal Performance}

Strontium and actinide removal testing occurred in triplicate at a MST solids concentration of $0.1 \mathrm{~g} \mathrm{~L}^{-1}$. This testing featured two MST samples produced by Optima Chemical Group Ltd (Douglas, GA) identified as Optima \#00-QAB-417 and Optima \#96-QAB-281 and one sample produced by Blue Grass Chemical Specialties, Inc. (New Albany, IN) identified as BGCS-2573. We combined $25 \mathrm{~mL}$ of the simulant with the appropriate MST sample in a 
plastic bottle and then placed the bottle in a waterbath shaker. We agitated the test bottles at $175 \mathrm{rpm}$ with the temperature maintained at $25 \pm 3 \cdot \mathrm{C}$.

After 48 hours of mixing we sampled each test bottle by filtering approximately $6 \mathrm{~mL}$ of the test mixture through a 0.45 -micron syringe filters (of nylon membrane) to remove MST solids. We collected and submitted the filtrate for chemical and radiochemical analyses. Gamma spectroscopy measured the ${ }^{85} \mathrm{Sr}$ and neptunium content. We measured the ${ }^{238,239,240} \mathrm{Pu}$ content by radiochemical separation of the plutonium followed by alpha counting of the extracted plutonium. Total strontium was determined by inductively coupled plasma emission spectroscopy (ICP-ES).

\subsection{RESULTS AND DISCUSSION}

\subsection{Particle Size Specification}

Procurement of MST uses a particle size specification originally developed for the ITP process. The specification required less than 1 vol $\%$ of the MST particles to be less than $1 \mu$ and less than 1 vol \% of the particles to be greater than $35.5 \mu$. The $1 \mu$ and $35.5 \mu$ sizes represented specific size channels reported by an earlier model of the Microtrac particle size instrument. SRNL currently uses Microtrac Model \#S3000 to measure particle size distribution of solid samples. This instrument measures particle sizes over the range from 0.0262 to $1408 \mu$. The typical output of the SRNL instrument does not include values for $1 \mu$ and $35.5 \mu$, but does include results for $0.972 \mu$ and $37 \mu$. We recommend that the particle size be evaluated at these values $(0.972 \mu$ and $37 \mu)$. Adoption of these values provides a slightly larger particle size range compared to that originally selected for the ITP facility. The small increase in the particle size range is not sufficient to affect ARP facility performance.

The original adoption of a particle size specification for large particles was intended to limit the quantity of particles that would be more difficult to suspend in the large processing tanks (i.e., Tanks $48 \mathrm{H}$ and $49 \mathrm{H}$ ) planned for the ITP process. The ARP facility plans to use a much smaller tank with central agitation. Thus, mixing conditions in the ARP facility strike tank are improved compared to those in the large processing tank used in the ITP process. Therefore, the ARP facility should be able to accommodate a higher fraction of large particles. However, larger particles may be less effective for removing strontium and actinides as the larger particles have a smaller surface area relative to the particle volume. Thus, we recommend keeping the particle size specification for larger particles unchanged (i.e., less than 1 vol \% of the particles be greater than $37 \mu$ ).

The lower particle size specification was originally intended to protect against rapid plugging of the crossflow filter membrane. Both the Salt Waste Processing Facility and ARP use MST to affect strontium and actinide removal from nuclear waste solutions. Unlike the earlier ITP process that contained mainly potassium and sodium tetraphenylborate solids and small amounts of MST and sludge solids, these processes will filter suspensions that contain only MST and sludge solids. Thus, the SRS Closure Business Unit requested that SRNL examine 
existing data and determine whether the particle size specification of the MST should be revised. The authors reviewed previous SRNL particle size and filter performance testing and the technical literature to evaluate and develop a new particle size specification for the procurement of MST.

Tarleton and Wakeman investigated the effect of particle size and pore size on filter fouling. ${ }^{5}$ They found feed solutions with smaller median particle size reduce filter flux more rapidly. They observed that the smaller particles in the feed are responsible for the fouling or cake layer in or on the membrane and that the median particle size is a poor indicator of fouling potential. They suggested comparing the $10^{\text {th }}$ percentile particle size to the $90^{\text {th }}$ percentile pore size. When this ratio is significantly greater than 1 , they observed much less pore fouling.

Wakeman investigated the impact of particle size variability on particle packing density and porosity for different solids including calcite, anatase and china clay. ${ }^{6}$ He found a good correlation between the particle size geometric standard deviation, which he defined as the ratio of the particles measured at the $50^{\text {th }}$ and $16^{\text {th }}$ percentiles (i.e., $50^{\text {th }}$ percentile $/ 16^{\text {th }}$ percentile), and the particle packing density. The geometric standard deviation provides a measure of the breadth of particle sizes for a particular sample. In general, a smaller geometric standard deviation results in better filter performance.

In consideration of these methodologies, we evaluated the particle size and filtration data from two samples of MST supplied by Optima Chemical Group Ltd. identified as 95-QAB-451 and 00-QAB-417 and two samples supplied by Blue Grass Chemical Specialties, LLC identified as BGCS-2753 and BGCS-2753 Rework. Table 2 reports the mean particle size, geometric standard deviation and volume percent below $0.8 \mu$ as well as volume percent greater than $37 \mu$. The $0.1 \mu$ Mott media is the filter media planned for use in the ARP facility. We selected the $0.8 \mu$ particle-size value to report as this represents the absolute pore size of the $0.1 \mu$ Mott filter media.

The mean particle size of the four samples ranged from 2.2 to $10.2 \mu$. The geometric standard deviation and volume percent below $0.8 \mu$ ranged from 1.9 to 3.5 and 3.5 to 10 , respectively. The larger difference in particle size characteristics between the two BGCS samples reflects classification of the original sample (BGCS-2753) to remove larger particles. As a consequence of this operation, the reworked material exhibits a smaller mean particle size and geometric standard deviation and greater fraction of particles less than $0.8 \mu$ in size. 


\section{Table 2. MST Particle Size Data Based on Measurements Performed with a Microtrac S3000 Instrument}

\begin{tabular}{|c|c|c|c|c|}
\hline Sample & $\begin{array}{c}\text { Mean } \\
\text { Size }(\mu) \\
\end{array}$ & $\begin{array}{c}\text { Geometric } \\
\text { Std. Dev. }\end{array}$ & $\begin{array}{l}\text { Vol \% } \\
\leq 0.8 \mu \\
\end{array}$ & $\begin{array}{l}\text { Vol \% } \\
>37 \mu \\
\end{array}$ \\
\hline Optima 95-QAB-451 & 5.8 & 3.5 & 5.0 & 0.36 \\
\hline Optima 00-QAB-417 & 5.1 & 3.0 & 4.6 & 0.67 \\
\hline BGCS-2753 & 10.2 & 2.9 & 3.5 & 3.48 \\
\hline BGCS-2753Rework & 2.2 & 1.9 & 10 & 0 \\
\hline
\end{tabular}

Table 3 shows the filter flux data with four of the MST samples and three different filter media. With the $0.45-\mu$ Nalgene filters and the $0.1-\mu$ Mott filters, we observed no difference in the filtration rates among the MST samples that were tested. Note, however, that the filter flux was considerably lower with the larger $0.1-\mu$ Mott filter $(0.8 \mu$ absolute size $)$ than the smaller $0.45-\mu$ Nalgene filter. With the $0.5-\mu$ Mott filter, which has an absolute membrane size of $2.2 \mu$, we measured a significant difference in the filtration rates between the Optima and BGCS samples of MST. Note, that the filtrate rates for the 0.5- $\mu$ Mott filter measured higher than those measured with the $0.1-\mu$ Mott filter. Thus, filtrate rate does not vary linearly with absolute filter size.

Table 3. Filtration Test Results

\begin{tabular}{|c|c|c|c|c|c|}
\hline \multirow[b]{2}{*}{ Filter ID } & \multirow[b]{2}{*}{$\begin{array}{c}\text { Absolute } \\
\text { Size }(\mu)\end{array}$} & \multicolumn{3}{|c|}{ Average Filtration Rate $\left(\mathrm{mL} \mathrm{s}^{-1}\right)^{\mathrm{a}}$} & \multirow[b]{2}{*}{$\begin{array}{c}\text { BGCS } \\
\text { \#2753 Rework }\end{array}$} \\
\hline & & $\begin{array}{c}\text { Optima } \\
\text { 00-QAB-451 }\end{array}$ & $\begin{array}{c}\text { Optima } \\
\text { 00-QAB-417 }\end{array}$ & $\begin{array}{l}\text { BGCS } \\
\# 2753\end{array}$ & \\
\hline $0.45 \mu$ Nalgene & 0.45 & $\mathrm{~nm}$ & $2.24(0.25)$ & $2.50(0.075)$ & $2.15(0.065)$ \\
\hline $0.1 \mu$ Mott & 0.8 & $0.29(0.0026)$ & $0.25(0.032)$ & $0.23(0.044)$ & $0.28(0.025)$ \\
\hline $0.5 \mu$ Mott & 2.2 & $\mathrm{~nm}$ & $1.78(0.20)$ & $0.64(0.019)$ & $0.71(0.043)$ \\
\hline
\end{tabular}

Since all four MST samples exhibited the same filtration rate with the $0.1 \mu$ Mott filter, we conclude that all of the materials will provide the same filtration rates in the SWPF and ARP facility. The portion of particles below $0.8 \mu$ ranged from 3.5 to $10 \mathrm{vol} \%$ among the four MST samples. The geometric standard deviation ranged from $1.9-3.5$. Given that the $0.1 \mu$ Mott filtration rate was not significantly different among these MST samples, we concluded that MST samples with up to $10 \mathrm{vol} \%<0.8 \mu$ and geometric standard deviation of $\leq 3.5$ are 
acceptable for use with the $0.1 \mu$ Mott filter. Thus, we recommend the following particle size specifications for MST for use with $0.1 \mu$ Mott filter,

- less than 10 vol $\%$ of the MST particles be less than $0.8 \mu$,

- the particle size geometric standard deviation be $\leq 3.5$, and

- less than $1 \mathrm{vol} \%$ of the MST particles greater than $37 \mu$.

Note that the development of this particle size specification is based on a small data set. There is a risk that a batch of MST that meets this particle size specification may exhibit a lower filtration performance than desired. We recommend that additional batches of MST received at SRS for use in ARP be analyzed for particle size and filtration performance. This will increase the available database and provide increased confidence that particle size parameters are an accurate prediction of filtration performance.

If the crossflow filter media features a smaller pore size, we recommend adjusting the specification for the pore size (absolute) for the filter media. This minimizes the possibility of plugging the pores of the filter media. Thus, for the $0.1 \mu$ Pall Accusep filter $(0.1 \mu$ absolute), we recommend that less than 10 vol $\%$ of the particles be less than $0.1 \mu$. Any MST batch meeting the requirements for the $0.1 \mu$ Mott filter will meet the requirements for the $0.1 \mu$ Pall Accusep filter. Table 4 provides a summary of the particle size specifications for the $0.1 \mu$ Mott and $0.1 \mu$ Pall Accusep filters.

\section{Table 4. Particle Size Specifications for Acceptance of MST}

\begin{tabular}{|c|c|c|c|c|}
\hline $\begin{array}{l}\text { Filter } \\
\text { Media }\end{array}$ & $<0.1 \mu$ & $<0.8 \mu$ & $>37 \mu$ & $\begin{array}{l}\text { Geometric } \\
\text { Std. Dev. }\end{array}$ \\
\hline $0 . \overline{1 \mu \text { Pall }}$ & $<\overline{10 \mathrm{vol} \%}$ & & $<\overline{1 \mathrm{vol} \%}$ & $\leq 3.5$ \\
\hline $0.1 \mu \mathrm{Mott}$ & & $<10$ vol \% & $<1$ vol \% & $\leq 3.5$ \\
\hline
\end{tabular}

\subsection{Strontium Decontamination Factor (DF) Specification}

Currently SRNL uses a radiochemical method for determining the strontium removal performance of MST samples prepared by vendors. ${ }^{7}$ In this method, a simulated waste solution is spiked with a radiotracer, ${ }^{85} \mathrm{Sr} .{ }^{85} \mathrm{Sr}$ emits gamma rays, which can be readily detected. Gamma activity is measured before and after contact with $0.5 \mathrm{~g} \mathrm{~L}^{-1}$ of MST for 48 hours. The ratio of the gamma activity before and after contact is defined as the strontium DF. The radiochemical method can detect very low concentrations of ${ }^{85} \mathrm{Sr}$ with excellent accuracy and precision.

The strontium DF value provides a measure of the performance of the material under conditions similar to operations in planned site facilities. Thus, it serves as a key characteristic by which the site accepts delivery of a batch of MST. Previous purchase specifications for MST required that the material have a strontium DF of at 150 per the standard radiochemical method. ${ }^{7,8,9}$ 
Previous vendors of MST have not been able to measure the strontium DF for their materials as they do not have access to radioanalytical facilities. Typically, vendors sent qualification samples to SRNL to measure the strontium DF. Developing a non-radiochemical method for determination of the strontium DF would allow vendors to measure the strontium DF prior to delivery of the material to SRS.

There are a number of techniques for measuring stable strontium concentrations in aqueous solutions including atomic emission spectroscopy and mass spectroscopy. Both of these methods are widely used at SRS and the chemical industry. SRNL offers these analytical methods, which are coupled with inductively coupled plasma system for introducing the sample into the desired emission or mass spectrometer.

Both the inductively coupled plasma emission spectroscopy (ICP-ES) and inductively coupled plasma mass spectroscopy (ICP-MS) offer good accuracy and precision. However, both of these techniques feature much higher detection limits than that offered by gamma counting. Thus, the use of the ICP-ES and ICP-MS methods requires that the strontium concentrations in the simulated waste solutions be much greater than that using the gamma counting method.

We measured the removal of strontium after a 48-hour contact with each of the three MST samples in the three different simulated waste solutions. All three simulants contain the same bulk chemical compositions, but differ in concentrations of strontium and actinides. Simulant SSS-8-2004 was developed for testing the performance of MST in support of the Salt Waste Processing Facility (SWPF) and ARP facility and contains a much lower stable strontium concentration $\left(0.484 \pm 0.032 \mathrm{mg} \mathrm{L}^{-1}\right)$ compared to the other two simulants $\left(5.23 \pm 0.193\right.$ and $\left.5.66 \pm 0.16 \mathrm{mg} \mathrm{L}^{-1}\right)$. This simulant is the only one that contains plutonium, neptunium and uranium. On a total sorbate cation equivalent basis, the two high strontium simulants contain about 20-30\% more equivalents than the simulant with strontium and actinides (see Table 1).

For these tests we contacted the simulated waste solutions with MST samples at a concentration of $0.1 \mathrm{~g} \mathrm{~L}^{-1}$. This concentration is well below the MST concentration of $0.5 \mathrm{~g} \mathrm{~L}^{-1}$ used in the radiochemical method ${ }^{7}$ and the planned concentration of $0.4 \mathrm{~g} \mathrm{~L}^{-1}$ for the ARP facility. We selected the lower concentration to provide reduced strontium removal so that the strontium concentration in the treated solution could be quantified by the ICP-ES or ICP-MS analytical method.

Prior to testing with MST samples, we determined the concentration of strontium in an alkaline salt solution using both the ICP-ES and ICP-MS instruments. The analytical results agreed well for both methods. The ICP-ES method reported an analytical uncertainty of about $10 \%$ compared to that of $30 \%$ by ICP-MS. The ICP-ES method also proves more cost effective than the ICP-MS. Given the improved accuracy and lower cost, we selected the ICP-ES method for measurement of strontium concentrations in the MST strontium DF test method. 
Table 5 provides the measured strontium, plutonium and decontamination factors for each of the MST samples with each simulant. The reported values are the average and single standard deviation of triplicate measurements. We observe that the Optima \#00-QAB-417 and BGCS \#2753 exhibited similar strontium DFs, which are higher than those measured for Optima \#96-QAB-281. This is the expected trend as the first two MST samples had previously demonstrated excellent strontium removal (DF $>150$ per standard test), ${ }^{10}$ whereas Optima \#96-QAB-281 exhibited poorer strontium removal (DF <150 per standard test). ${ }^{11,12}$

Table 5. Strontium, Plutonium and Neptunium Decontamination Factors

\begin{tabular}{|c|c|c|c|c|}
\hline Simulant ID & $\begin{array}{c}\text { Analytical } \\
\text { Method }\end{array}$ & $\begin{array}{c}\text { Optima } \\
\text { \#00-QAB-417 }\end{array}$ & $\begin{array}{l}\text { BGCS } \\
\# 2753\end{array}$ & $\begin{array}{c}\text { Optima } \\
\end{array}$ \\
\hline
\end{tabular}

Strontium Decontamination Factor

$\begin{array}{ccccr}\text { SWS-7-2005-1 } & \text { ICP-ES } & 2.12 \pm 0.183 & 2.38 \pm 0.170 & 1.59 \pm 0.056 \\ \text { SWS-7-2005-2 } & \text { ICP-ES } & 2.02 \pm 0.023 & 1.95 \pm 0.079 & 1.41 \pm 0.189 \\ & \text { Gamma Counting } & 3.08 \pm 0.118 & 2.66 \pm 0.207 & 1.70 \pm 0.348 \\ & & & & \\ \text { SSS-8-2004 } & \text { Gamma Counting } & 8.75 \pm 0.183 & 10.3 \pm 1.26 & 1.56 \pm 0.287\end{array}$

Plutonium Decontamination Factor

$\begin{array}{llll}\text { SSS-8-2004 Alpha Counting } & 2.83 \pm 0.151 & 2.45 \pm 0.198 & 1.29 \pm 0.067\end{array}$

Neptunium Decontamination Factor
SSS-8-2004
Gamma Counting
$1.05 \pm 0.036$
$1.10 \pm 0.124$
$1.06 \pm 0.058$

Tests with simulant SWS-7-2005-2 afforded the opportunity to compare directly two different analytical methods, ICP-ES and radiochemical (gamma counting), for the determination of the strontium DF. For all three MST samples, the strontium DF values measured by ICP-ES measured lower - by 18 to $35 \%$ - than those determined by the radiochemical method. Note, that at the $95 \%$ confidence limit, the strontium DF values measured by ICP-ES in simulant SWS-7-2005-2 are not statistically different than those measured in simulant SWS-7-2005-1. Furthermore, we observed the same trend in performance among the three MST samples. Thus, we conclude that using the high strontium simulant, adding the MST sample at a concentration of $0.1 \mathrm{~g} \mathrm{~L}^{-1}$ and measuring strontium concentrations by ICP-ES is feasible for evaluating the strontium removal performance of MST samples. 
We observed a much greater difference in the strontium DF values in the lower stable strontium simulant (SSS-8-2004) particularly for the Optima \#96-QAB-281 sample. Clearly, this simulant provides a better test platform for distinguishing strontium performance. However, the reduced initial stable strontium concentration $\left(0.484 \mathrm{mg} \mathrm{L}^{-1}\right)$ results in a stable strontium concentration after contact with MST that is below the quantifiable limit of the ICP-ES method.

Plutonium removal performance in this simulant follows the same trend as observed for strontium. Note, however, that neptunium removal among the three MST samples was not significantly different. Given the same trends in strontium and plutonium removal with the low and high strontium simulants, we conclude that measurement of the strontium DF value using a high strontium simulant and ICP-ES as the analytical method provides an acceptable method to evaluate the strontium and actinide removal performance of MST samples.

Given the testing results for the non-radiochemical method for evaluating strontium removal performance of MST samples, we recommend modifying the purchase specification to include a requirement that the MST exhibits a strontium DF factor of $>1.79$ - i.e., the lower $95 \%$ confidence value of $1.95-2 * 0.079$ - upon contact of a simulated waste solution having the composition as reported for SWS-7-2005-1 in Table 1 and containing 5.2 to 5.7 $\mathrm{mg} \mathrm{L}^{-1}$ strontium with $0.1 \mathrm{~g} \mathrm{~L}^{-1}$ of the MST. We also recommend that additional tests with these simulants and MST samples and, if available, new MST samples, to determine the reproducibility and increase the available database for the measurements by the ICP-ES instrument. This additional scope will provide increased confidence that the non-radiological method provides a reliable method for evaluating the strontium and actinide removal performance for MST samples. 


\subsection{CONCLUSION AND RECOMMENDATIONS}

Savannah River National Laboratory (SRNL) evaluated the previous purchase specifications for particle size and strontium decontamination factor. Based on the measured particle size and filtration performance characteristics of several MST samples with simulated waste solutions and various filter membranes we recommend that the particle size specification be changed to the following. The recommended specification varies with the size and manufacturer of the filter membrane as shown below. We recommend that future batches of MST received at SRS be tested for particle size and filtration performance. This will increase the available database and provide increased confidence that particle size parameters are an accurate prediction of filtration performance.

\begin{tabular}{|c|c|c|c|c|}
\hline $\begin{array}{l}\text { Filter } \\
\text { Media }\end{array}$ & $\leq 0.1 \mu$ & $\leq 0.8 \mu$ & $\geq 37 \mu$ & $\begin{array}{l}\text { Geometric } \\
\text { Std. Dev. }\end{array}$ \\
\hline $0.1 \mu$ Pall & $<10$ vol \% & & $<1 \mathrm{vol} \%$ & $\leq 3.5$ \\
\hline $0.1 \mu \mathrm{Mott}$ & & $<10$ vol \% & $<1$ vol \% & $\leq 3.5$ \\
\hline
\end{tabular}

Testing demonstrated the feasibility of a non-radiochemical method for evaluating strontium removal performance of MST samples. Using this analytical methodology we recommend that the purchase specification include the requirement that the MST exhibits a strontium DF factor of $>1.79$ upon contact of a simulated waste solution as reported for SWS-7-2005-1 in Table 1 and containing 5.2 to $5.7 \mathrm{mg} \mathrm{L}^{-1}$ strontium with $0.1 \mathrm{~g} \mathrm{~L}^{-1}$ of the MST. We also recommend that additional tests with these simulants and MST samples and, if available new MST samples, to determine the reproducibility and increase the available database for the measurements by the ICP-ES instrument. This approach will provide increased confidence that the non-radiological method provides a reliable method for evaluating the strontium and actinide removal performance for MST samples. 


\subsection{REFERENCES}

${ }^{1}$ MST Specification Development, SP-TTR-2005-00001, Rev. 0, February 9, 2005.

${ }^{2}$ Hobbs, D. T.; Poirier, M. R. "Task Technical and Quality Assurance Plan for Development of Monosodium Titanate (MST) Purchase Specifications”, WSRC-RP-2005-01631, Revision 0, June 2005.

3 Hobbs, D. T.; Blume, M. S.; Thacker, H. L. "Phase V Simulant Testing of Monosodium Titanate Adsorption Kinetics,” WSRC-TR-2000-00142, Rev. 0, May 24, 2000.

${ }^{4}$ Hobbs, D. T.; Blume, M. S.; Thacker, H. L. "Screening Evaluation of Alternate Sorbents and Methods for Strontium and Actinide Removal from Alkaline Salt Solution,” WSRC-TR-2001-00072, Rev. 0, February 2001.

5 Tarleton, E. S.; Wakeman, R. J. "Understanding Flux Decline in Crossflow Microfiltration: Part I-Effects of Particle and Pore Size", Trans ChemE, Part A, 1993 (71), 399-410.

6 Wakeman, R. J. "Packing Densities of Particles and Log-Normal Size Distributions", Powder Technology, 1975 (11), 297-299.

${ }^{7}$ Savannah River National Laboratory Procedure Manual, Manual 12.1, Waste Processing Technology Section Procedure IWT-OP-033, Rev. 4, February 28, 2002, Determination of the Equilibrium Distribution Constant for Monosodium Titanate Samples (U).

${ }^{8}$ Procurement Specification for Monosodium Titanate, Z-SPP-H-00001, Rev. 2, May 1992.

${ }^{9}$ Specification for Procurement of Monosodium Titanate Slurry for ARP, 512-S, X-SPP-S-00021, Rev. 0, February 5, 2003.

${ }^{10}$ Hobbs, D. T.; Nyman, M. D.; Clearfield, A. "Tailoring Inorganic Sorbents for SRS Strontium and Actinide Separations: Optimized Monosodium Titanate and Pharmacosiderite Phase I Final Report," WSRC-TR-200400322, Rev. 0, July 2004.

${ }^{11}$ Fink, S. D.; Hobbs, D. T.; Peters, T. B. "Demonstration of MST Efficacy on Removal of Actinides and Strontium in 'Bounding Alpha' Waste," WSRC-TR-2002-00555, Rev. 0, December 17, 2002.

${ }^{12}$ Peters, T. B; Fink, S. D.; Hobbs, D. T.; Norato, J. A.; Walker, D. D. "Demonstration of MST and Permanganate Efficacy on Removal of Actinides and Strontium from Savannah River Site High Level Waste," WSRC-TR-2002-00355, Rev. 0, March 11, 2003. 